Basa, Enikő M. "Vörösmarty, Mihály. Csongor és Tünde, Csongor and Tünde - a Fairy Tale Play in Verse. Trans. Peter Zollman [parallel Hungarian-English edition]. Winnetka: CreateSpace Independent Publishing Platform, 2017. 80 pp." Hungarian Cultural Studies. e-Journal of the American Hungarian Educators Association, Volume 11 (2018) DOI: 10.5195/ahea.2018.330

\title{
Vörösmarty, Mihály. Csongor és Tünde, Csongor and Tünde - a Fairy Tale Play in Verse. Trans. Peter Zollman [parallel Hungarian- English edition]. Winnetka: CreateSpace Independent Publishing Platform, 2017. 80 pp.
}

\author{
Reviewed by Enikő M. Basa", Library of Congress
}

The translation of Mihály Vörösmarty's masterpiece drama makes available to the English-language readership one of the most important, and most popular, works of the Hungarian Romantic poet (1801-1855). In his Oxford History of Hungarian Literature from the Earliest Times to the Present, Lóránt Czigány observes that Vörösmarty's "reputation as a playwright rests solely on this light-hearted piece. Csongor and Tünde is regarded by many of Vörösmarty's critics as the climax of his poetic achievement" (Oxfordshire: Clarendon Press, 1984, 130). Vörösmarty's literary output, however, is much broader and includes a patriotic epic, Zalán futása ['The Flight of Zalán'], on the settlement of the Hungarians, and "Szózat" ['Appeal'], which is considered the second national anthem, as well as numerous lyrical poems, many of which have patriotic themes.

Csongor és Tünde is a play that calls for free choice in both the personal and social or national spheres. In the opening lines Csongor, the main protagonist, declares that he is looking for "the lady of his dreams," but in his quest for his Love he necessarily also has to face social and political challenges, as in the poetic-dramatic tradition and political reality of the playwright's time these two missions were seen as intertwined and mutually mirrored or symbolized. Czigány explains how a light-hearted poetic drama can carry a cardinal political message: "the imagery is well adapted to his poetic world... in which abstract notions patriotism, country - are translated into human emotions. Vörösmarty’s politics is a burning love-affair, an immortal passion subject only to the natural oscillation of his innermost self" (135).

In view of the poet's commitment to ideal notions of love and statehood, the readers of his play might want to consider questions of human dignity and free choice in this seemingly fanciful drama of his. Thematically, however, the plot is anchored in the sixteenth-century Hungarian Árgirius romance, and it also carries influences of William Shakespeare's Midsummer's Night's Dream (1595-1596), whereas resistance to authority is but a subtextual theme in it and will only emerge in the final scene. Yet, Vörösmarty's questions are substantially much more existential than poetic: "Are human beings capable of achieving happiness? Is there a kind of happiness that completely satisfies man?” (Czigány 130). The answer, coming from the

*eniko.basa@verizon.net

(cc) $\mathrm{Br}$

ULLS D-Serle
New articles in this journal are licensed under a Creative Commons Attribution 4.0 International License.

This journal is published by the University Library System of the University of Pittsburgh as part of its D-Scribe Digital Publishing Program and is cosponsored by the University of Pittsburgh Press 
Basa, Enikő M. "Vörösmarty, Mihály. Csongor és Tünde, Csongor and Tünde - a Fairy Tale Play in Verse. Trans. Peter Zollman [parallel Hungarian-English edition]. Winnetka: CreateSpace Independent Publishing Platform, 2017. 80 pp." Hungarian Cultural Studies. e-Journal of the American Hungarian Educators Association, Volume 11 (2018) DOI: 10.5195/ahea.2018.330

mouth of Vörösmarty's main protagonist (and rendered here in Zollman's rather down-to-earth English), is that only "reciprocated love" can solve these mysteries:

Csongor: These travelers won't guide me on my journey.

The first one worships gold dust as in his idol, the next would turn us into prisoners to rule a world of battles and destruction. But this one is the vilest of them all: he walks like death upon his spindly legs and wears a tombstone in his sickly chest. Come loving passion, be my guiding star, And lead me on my way to Fairyland (618-624).

['Csongor: S igy utazóim útra nem vezetnek.

Egyik, mint bálványt, hitvány port ölel,

A másik rommá tenné a világot,

Csak hogy fölötte ö lehessen úr.

$S$ a legszörnyebb mindenek között:

Mint a halál jár élö lábakon, És puszta sirt hord hö kebel helyett.

Óh, szerelem, gyujtsd utamra csillagod, S te légy vezérem Tünderhon felé'] (618-624).

Csongor soon realizes that the paths of the three travelers he has described in the lines just quoted are futile, but it is Balga, Csongor's realistic companion, who offers earth-based alternatives to Csongor's lofty ideals. Textually, Vörösmarty's employment of these two figures and use of both lyric and realistic speech externalize the contrast or clash between the drama's two opposing poles, which is expressed by Tünde in the following lines:

Tünde: That was not a jest I told you.

Long ago, a blushing maiden

whispered a word to her sweetheart

and her cheeks turned rosy pink, more enchanting than the Dawn's.

Ever since then, in this Kingdom, sweetheart mustn't speak to sweetheart, or she forfeits him forever (897-904).

['Tünde: Csak valóság amit mondasz. Hogy legelsőbb kedveséhez

A szerelmes lányka szolt, Elpirultak araci, S szebbnek lőnek Hajnalénál, 
És azóta e hazában

Amely lány szól kedveséhez, Eljátszotta kedvesét'] (897-904).

While on his quest, Csongor has to face the scheming of ill-meaning Suckbane [Hung. Mirigy], who plots against him, while Csongor receives only little help from others, except for Balga, who keeps grounding him in reality. As expected, in the play's finale all of its earth-bound as well as ethereal entanglements are resolved. The three travelers break apart, the lovers are united and Tünde calls upon her Love:

Tünde: Csongor dear, the words grow weary, reason is incompetent.

Come and rest in my embraces, Hold me firm in your embraces. Undivided, undisturbed, we shall live here, man and wife, far away from daily strife, moved by love, at peace with life wouldn't change it for the world (2432-2441).

['Tünde: Csongor, ah, elfárad a szó.

És az ész elégtelen, Jer, nyugodjál e karok közt

S hagyi nyugomnom karjaid közt.

Háborithatlannul

Így fogunk mi csendben élni, $S$ a bajoktól messze lenni; Így fogunk mi kéjben élni, S a világgal nem cserélni'] (2432-2441).

In his translation Peter Zollman (1931-2014), a Jewish-born Hungarian engineer who fled to England in 1956 and upon retirement took up or rather returned to his young-age love of poetry, manages to capture the play's sense of lyricism and its pathos. As publisher John A. Sarkett points out in the book's introductory part:

The perspective of cosmic beginning and end bound up to produce an effect of meaninglessness in the miniature of human world, yet it is precisely this little world of earthlings for which Tünde gives up her fairy world, and it is the bond between Csongor and Tünde which provides Vörösmarty with his escapist solution and his last refuge in an irrational world: love. Love provides that "fleeing moment of happiness" which all mankind pursues vainly (23). 
Basa, Enikő M. "Vörösmarty, Mihály. Csongor és Tünde, Csongor and Tünde - a Fairy Tale Play in Verse. Trans. Peter Zollman [parallel Hungarian-English edition]. Winnetka: CreateSpace Independent Publishing Platform, 2017. 80 pp." Hungarian Cultural Studies. e-Journal of the American Hungarian Educators Association, Volume 11 (2018) DOI: 10.5195/ahea.2018.330

In evaluating the language of the translation, I would say that it is felicitous, with the opening lines reverberating the atmosphere of the original play:

Csongor: I have searched in every nation, every land upon the earth for that infinitely rare beauty, far beyond belief, for the lady of my dreams (1-5).

['Csongor: Minden országot bejártam

Minden messze tartományt, S aki álmaimban él, A dicsöt az égi szépet Semmi földön nem találtam'] (1-5).

The same can be said of several lyrical passages, as in this instance:

(Song) Slumber, slumber, gentle slumber sing your silent serenade.

All you true hears

play your two parts

one to woo and one to wait (181-186).

['(Dal) Álom, álom,

Édes álom

Szálj csendes föld fölé;

Minden örszem

Hulljon, csak nem

A várt s várró kedvesé'] (181-186).

The contrast of Tünde and Ilma, also called Böske, Balga's wife, is likewise gracefully depicted and translated in the following portion from the dialogue between them in the second act:

Ilma: Madam, you are right to ask me:

"Ilma, tell me what to do."

I was born upon this earth

You was born up in the skies, planted somewhere mighty far in the Plough's most shiny star. Then the tempest swept you down from your fairy paradise, down you fell and came to rest 
Basa, Enikő M. "Vörösmarty, Mihály. Csongor és Tünde, Csongor and Tünde - a Fairy Tale Play in Verse. Trans. Peter Zollman [parallel Hungarian-English edition]. Winnetka: CreateSpace Independent Publishing Platform, 2017. 80 pp." Hungarian Cultural Studies. e-Journal of the American Hungarian Educators Association, Volume 11 (2018) DOI: 10.5195/ahea.2018.330

straight on Master Csongor's breast.

Now you ask for my advice (424-434).

['Ilma: Azt igen bölcsen teszed,

Hogy tanácsomat kivánod,

Itt a földön, asszonyom,

Hol te, mint én, nem születtél,

Mert a göncöl csillagán

Úgy teremtél rózsafán;

S onnan egy vihar lerázott,

S Csongor úrfi kebelén

Virradál meg, ébredél fel!

Kinos édes érzeménnyel,

S most kérsz, hogy segitsek én'] (424-434).

While a bilingual person who can read the original would find it hard to overlook the overall lack of literariness or poeticality in this translation, the spirit of the original is still retained and none of the underlying meaning is lost. Still, the present edition of Vörösmarty's poetic-drama translated by Peter Zollman raises a few puzzling questions. The book's back-cover blurb touts this edition as a reprint of a long out-of-print translation, but at least I have not been able to find evidence of any such translation having been published ever before. The copyright is 1996 in Peter Zollman's name, so this would suggest that this is a translation he did years ago but never published thereafter and that therefore this is the translation's first and only publication. To support this assumption, the publication information on the book's first page states that a theatre production of Vörösmarty's play was performed in 1996, the $1100^{\text {th }}$ anniversary of the foundation of the Hungarian State, as well as the fortieth anniversary of the 1956 Hungarian Revolution. The credits further indicate that the present translation is based on that stage production, performed at the Merlin International Theater in Budapest to celebrate the double anniversary. This means that the work at hand is probably an abridged version and that the full poetic work is not rendered in either language. In effect, however, little is lost or amiss for the general reader. Moreover, the illustrations from the 1996 theatre performance enrich the present volume adding to it a lively dramatic and visual dimension. 